\title{
Preispitivanje interne komunikacije u visokom obrazovanju u ozračju bolesti COVID-19: smjernice za budućnost
}

\author{
Zdeslav Milas \\ Edward Bernays Visoka škola, Zagreb, Hrvatska \\ e-mail: zdeslav.milas@bernays.hr
}

\author{
Dorotea Milas \\ Poslovno veleučilište Zagreb, Hrvatska \\ e-mail:dorotea.milas@pvzg.hr
}

\begin{abstract}
SAŽETAK Godina 2020. ostaje zapamćena po pandemiji koronavirusa (SARS-CoV-2) svjetskih razmjera i radikalnoj promjeni način života. Interna komunikacija visokih učilišta postaje presudna u okolnostima prekida klasične nastave, zatvaranja zgrada za studente, prelaska na rad od kuće i uspostavljanja digitalnih platformi. Brza prilagodba organizacija na promjenu načina komunikacije sugerira da interna komunikacija postaje od strateškog značaja za daljnje funkcioniranje sveučilišta, fakulteta, veleučilišta i visokih škola.
\end{abstract}

Cilj ovoga rada jest analiza promjene paradigme interne komunikacije u ozračju koronavirusa u visokom obrazovanju unutar stručnih studija. Svrha je upoznati se s izazovima u internoj komunikaciji prilikom digitalne transformacije nastavnog procesa te odrediti jesu li se promijenili ciljevi i instrumenti u internoj komunikaciji visokog učilišta. Za istraživačku metodu odabran je polustrukturirani dubinski intervju s dekanima ili prodekanima za nastavu na uzorku od deset odabranih veleučilišta odnosno visokih škola koje izvode akreditirane stručne studije u Hrvatskoj. Metoda polustrukturiranog intervjua odabrana je zbog mogućnosti generiranja novih ideja i pitanja na temelju odgovora i iskustava ispitanika, koji su bili odgovorni za prilagodbu nastavnog procesa na daljinu i komunikaciju s nastavnicima i studentima. Radikalna promjena oblika nastave snažno je utjecala na digitalizaciju u visokom obrazovanju, a kroz analizu odgovora ispitanika autori daju smjernice za budućnost interne komunikacije kao strateške funkcije u upravljanju visokim učilištima. Postpandemijsko razdoblje stvara „novo normalno“ $\mathrm{u}$ funkcioniranju internih komunikacijskih procesa, koji su usko povezani s digitalnom transformacijom visokih učilišta.

Ključne riječi: interna komunikacija, digitalna transformacija, nastava na daljinu, komunikacija promjena, visoko učilište. 


\section{Uvod}

Najsnažnije obilježje 2020. godine jest pandemija bolesti uzrokovane koronavirusom (COVID-19). Osim što predstavlja zdravstvenu ugrozu, koronavirus je prvorazredni gospodarski problem i potpuno je promijenio način života. Od druge polovice ožujka 2020. godine život u Europi i Hrvatskoj postaje neprirodan i virtualan. Na visokim učilištima ljetni semestar akademske godine 2019./2020. tek je započeo, a ministar zdravstva proglašava epidemiju bolesti COVID-19 na području čitave Republike Hrvatske s danom 11. ožujkom 2020. godine (Ministarstvo zdravstva, 2020.). Dva dana nakon toga Vlada Republike Hrvatske na telefonskoj sjednici donosi odluku da se „obustavlja izvođenje nastave u visokim učilištima, srednjim i osnovnim školama“, provedba odluke počinje 16. ožujka 2020. godine i traje do opoziva, a Ministarstvo znanosti i obrazovanja zaduženo je za „dinamiku uspostave nastave na daljinu.“ (Odluka o obustavi izvođenja nastave u visokim učilištima, 2020.). Ovisno o razini tehnološke razvijenosti pojedinog visokog učilišta, unutar 24 sata pa do 14 dana, rektorati i dekanati implementiraju model nastave na daljinu. Od tog trenutka proglašavanja potpunog zatvaranja (engl. lockdown) interna komunikacija visokog učilišta postaje od strateškog značaja.

Prve rezultate prelaska na nastavu na daljinu objavljuje Ministarstvo znanosti i obrazovanja (2020.), koje je početkom travnja 2020. godine prezentiralo stanje na temelju 106 od 132 odgovora čelnika visokih učilišta prikupljenih upitnikom, od kojih je 91 javnih, a 15 privatnih visokih učilišta. Ispitanici su odgovarali na pitanja o koordinaciji rada tijekom prva dva nastavna tjedna u ožujku 2020. godine i vrednovanju pomoću nastave na daljinu, o mogućnostima završetka akademske godine ako se tijekom semestra ne bude moguće vratiti na kontaktnu nastavu te o financijskim implikacijama izvođenja nastave na daljinu. Interesantan je pokazatelj da su „sva visoka učilišta u upitniku [...] navela da u nastavi na daljinu koriste, pored sustava Merlin ili vlastitih sustava za održavanje nastave na daljinu, dodatne online platforme dostupne bez naplate..." (Ministarstvo znanosti i obrazovanja, 2020.).

U toj anketi Ministarstva nisu dostupne informacije o tome je li nastava na daljinu organizirana na način snimanja predavanja, postavljanja prezentacije bez predavanja ili kao virtualna nastava uživo uz mogućnost interakcije sa studentima. Osim organizacije visokog učilišta u novonastalim okolnostima, nov izazov stvara snažan potres u Zagrebu koji se dogodio 22. ožujka 2020. godine, nakon kojeg dvadesetak fakulteta Sveučilišta u Zagrebu ima oštećenja, a nekoliko zgrada postaje neupotrebljivo za nastavu (Zulić, 2020.).

Na stranicama Europske komisije ističe se, u okviru Pregleda obrazovanja i osposobljavanja za 2020., da su u Hrvatskoj „visoka učilišta uspješno prešla na nastavu na daljinu za vrijeme ograničenja kretanja“, dominantna ustanova koja je osigurala softver za 70 tisuća studenata Sveučilišni je računski centar (Srce), čiji je osnivač Sveučilište u Zagrebu (Europska komisija, 2021.). 
Istraživanje o utjecaju pandemije bolesti COVID-19 na digitalnu pismenost na javnim estonskim sveučilištima ukazuje na to da studenti traže više digitalnog sadržaja za vrijeme učenja na daljinu (e-učenje), poput nastavnih materijala i vježbi, te ukazuje na veću opterećenost studenata učenjem gradiva nego prije pandemije, iz čega proizlazi da uzrok tome nisu tehnološki problemi, nego upravljanje vremenom i planiranje u ispitnom procesu u novonastalim okolnostima digitalnog okruženja (Zalite i Zvirbule, 2020.).

\section{Teorijski okvir}

Interna komunikacija, koja je pored odnosa s medijima ključna disciplina unutar odnosa s javnošću organizacije (Grunig, Grunig i Dozier, 2002.; Lies, 2015.), postaje presudna među ključnim internim dionicima, a to su na visokom učilištu dekanat, studenti, nastavnici i studentska referada. Između sedam ključnih javnosti visokoškolske institucije najvažniji su „studenti, a potom profesori i fakultetsko osoblje“ (Tomić, 2016.: 433). U povezanoj korporativnoj komunikaciji interna komunikacija definira se kao „komunikacijski i informativni proces između članova“ organizacije ili poduzeća (Einwiller, Klöfer i Nies, 2006.: 221). Osim funkcije informiranja članova organizacije, smisao interne komunikacije jest poticanje integracije i identifikacije putem dijaloga između menadžmenta i zaposlenika, te time posljedično jačanje motivacije zaposlenika i učinkovitosti radnog procesa (Röttger, 2000.). Wolfgang Armbrecht (1992.) postavlja model interne komunikacije kojim se proces odnosa sa zaposlenicima strukturira na pet razina: prva počinje $s$ komunikacijom, zatim informacijom, treća je razina učinkovitost motivacije zaposlenika da bi se postigla integracija i u konačnici ostvarila identifikacija zaposlenika s organizacijom.

Interna komunikacija posebno dolazi do izražaja kada se događaju organizacijske promjene (Milas, 2011.). U tom kontekstu, neovisno radi li se o obrazovnoj ustanovi ili poduzeću, organizacijske promjene iziskuju komunikaciju tih promjena $s$ internim dionicima organizacije. Claudia Mast (2006.: 402) navodi da su ciljevi komunikacije promjena „poticanje novih obrazaca ponašanja i sprječavanje aktivnosti ili ponašanja koja mogu otežavati proces promjena u poduzeću“. Ističe da promjene mogu biti reorganizacija ustroja i radnih procesa, spajanje tvrtki i smanjenje broja zaposlenika. $\mathrm{U}$ tom smislu, promjena radnih procesa radikalan je prelazak na nastavu na daljinu, zabrana pristupa studentima u zgradu visokog učilišta, rad od kuće za nastavnike i djelatnike, koji iziskuje intenzivnu internu komunikaciju. Takve mjere proizlaze iz zdravstvene krize, koja je nastala u vanjskom okruženju i može se najbliže kategorizirati kao prirodna kriza. U tim okolnostima dolaze do izražaja i oblici kriznog komuniciranja (Jugo, 2017.).

Oblici su i alati interne komunikacije sastanci, telefonske konferencije, videokonferencije, interni časopisi i intranet u većim organizacijama, zatim oglasna ploča kao 
najstariji oblik, dok je elektronička pošta najčešći oblik interne komunikacije (Tkalac Verčić, 2015.). Digitalne tehnologije mogu biti snažni alati u silaznoj, ulaznoj i horizontalnoj komunikaciji između menadžmenta i zaposlenika. No, Argenti (2009.) upozorava na informacijsku preopterećenost zaposlenika, posebno u komunikaciji emailom. Navodi rezultate istraživanja tvrtke Forrester Research iz 2005. godine, po kojem 69\% korisnika korporativnog intraneta klasificira tu platformu kao jako korisnu, istodobno svega $44 \%$ ispitanika odgovara da je jednostavno pronaći traženu informaciju na intranetu.

Osim spomenute ankete Ministarstva znanosti i visokog obrazovanja (2020.) koja je usmjerena na provedbu nastave na daljinu i tematski slične analize Europske komisije (2021.), u Hrvatskoj još nema objavljenih istraživanja o internoj komunikaciji visokoobrazovnih ustanova koja su determinirana pandemijom bolesti COVID-19. $\mathrm{Na}$ primjer, na njemačkom govornom području ocjena stanja i prije pandemije jest da „interna komunikacija na visokim učilištima pretežito je neistraženo područje“ (Buchholz, 2019.: 141).

Zanimljivo istraživanje na početku pandemije u travnju 2020. godine a na uzorku od sedam velikih švicarskih poduzeća proveli su Katharina Krämer i Annete Pfizenmayer (2020.). Studija je posvećena digitalizaciji interne korporativne komunikacije. Rezultati pokazuju početni problem izostanka dijaloga između zaposlenika, ali i ubrzani pronalazak digitalnih alata. Novi komunikacijski kanali omogućili su drugačiji načini rada i takav će ostati nakon pandemije. Najveći izazov je kako ostvariti emocionalnu bliskost između zaposlenika dok fizička udaljenost onemogućava rad u uredu, budući da su bez obzira na COVID-19 ciljevi interne komunikacije ostali isti.

\section{Metodologija istraživanja}

Cilj ovoga rada jest analiza promjene paradigme interne komunikacije u ozračju koronavirusa u visokom obrazovanju na stručnim studijima. Svrha je upoznati se s izazovima u internoj komunikaciji prilikom digitalne transformacije nastavnog procesa te usporediti jesu li se promijenile strategije, ciljevi, procesi i instrumenti u internoj komunikaciji veleučilišta i visokih škola.

Strukturirano je dvanaest pitanja u pet tematskih skupina (klastera), iz kojih je oblikovano pet istraživačkih pitanja. Prvo istraživačko pitanje vezano je za stanje prije pandemije, tri su vezana za iskustva prelaska i adaptacije na digitalnu internu komunikaciju i nastavni proces, dok je peto istraživačko pitanje vezano uz preporuke za daljnju digitalnu transformaciju nastavnog procesa.

IP1: U kojoj su mjeri korištene digitalne platforme u internoj komunikaciji i je li se izvodio neki oblik online ili hibridne nastave na pojedinim kolegijima odnosno na razini studijskog programa prije proglašene pandemije? 
IP2: Kako je komunikacija promjena na visokom učilištu provedena u odnosu na prelazak na daljinu i rad od kuće za zaposlene nastavnike i vanjske suradnike u nastavi?

IP3: Kakva su bila prva iskustva studenata i nastavnika uoči završetka nastavnog procesa u ljetnom semestru i evaluacije kao priprema za novu akademsku godinu 2021./2022.?

IP4: Jesu li se adaptirali ciljevi, strategije i alati u internoj komunikaciji?

IP5: Koje se preporuke mogu dati u smislu digitalne transformacije nastavnog procesa?

Zakonodavac definira da su visoka učilišta organizirana kao ustanove, a njihove su vrste sveučilište i njegove sastavnice, tj. fakulteti i umjetničke akademije, te veleučilište i visoka škola. Veleučilišta i visoke škole organiziraju i izvode stručne studije, a sveučilišta izvode sveučilišne i mogu izvoditi stručne studije (Zakon o znanstvenoj djelatnosti i visokom obrazovanju [ZZDVO], NN 123/2003). Ovim istraživanjem obuhvaćena su isključivo veleučilišta i visoke škole. Na njima studira $29 \%$ ukupne studentske populacije, što čini nešto manje od 50 tisuća studenata stručnih studija (Vijeće veleučilišta, 2021.).

Odabran je kvalitativan pristup istraživanju s obzirom na to da je cilj istraživača razmotriti i analizirati procese unutar visokog učilišta u digitalnom okruženju na namjernom, neprobabilističkom uzorku. Radi se o čelnicima visokih učilišta, tj. dekanima, koji su najodgovorniji za upravljanje veleučilištem ili visokom školom. Za tri veleučilišta odgovorili su, po ovlaštenju dekana, njihovi prodekani za nastavu, koji su izravno odgovorni za provedbu i nadzor nastavnog procesa te komunikaciju s nastavnicima i studentima.

$\mathrm{Za}$ metodu je odabran polustrukturirani dubinski intervju s dekanima ili prodekanima za nastavu na uzorku od deset odabranih veleučilišta odnosno visokih škola koje izvode akreditirane stručne studije u Hrvatskoj. Kvalitativna istraživačka metoda dubinskog intervjua odabrana je kako bi se od dekana ili prodekana za nastavu dobili opisi i tumačenja iskustava upravljanja visokim učilištem tijekom prelaska na digitalne platforme kao i prikupile nove spoznaje o internoj komunikaciji (usp. Tkalac Verčić, Sinčić Ćorić, Pološki Vokić, 2010.; Bedeković, 2011.).

Prema popisu Agencije za znanost i visoko obrazovanje, tijekom 2020. godine u Hrvatskoj stručne studije izvodi 36 veleučilišta i visokih škola, od kojih je 12 javnih i šest privatnih veleučilišta te dvije javne i 15 privatnih visokih škola (Agencija, 2020.). Uzorak pokriva sedam veleučilišta, od kojih su četiri javna i tri u privatnom vlasniš- 
tvu, s tim da je jedno privatno veleučilište u Zagrebu u stvarnom vlasništvu Grada Zagreba. Jedno privatno veleučilište pripojeno je u siječnju 2021. godine privatnom sveučilištu iste vlasničke strukture, ali to ne mijenja meritum ovog istraživanja jer je de facto zimski semestar akademske godine 2020./2021. završen u okviru veleučilišta. Sve tri visoke škole u uzorku u privatnom su vlasništvu. Veleučilišta su visoka učilišta koja izvode studijske programe iz barem triju različitih znanstvenih polja, dok su visoke škole usko povezane $s$ izvođenjem studijskih programa iz jednog ili dvaju znanstvena polja (ZZDVO, NN 123/2003). U pravilu, na veleučilištima studira veći broj studenata. U uzorku je pokriveno $27,78 \%$ svih veleučilišta i visokih škola, od toga 38,9\% veleučilišta i $17,64 \%$ visokih škola, što jamči reprezentativnost ovog istraživanja (vidi tablicu 1).

Tablica 1.

Sastav uzorka po vrsti, vlasničkoj strukturi i teritorijalnom aspektu ${ }^{1}$

\begin{tabular}{|c|c|c|c|c|c|}
\hline R.br. & Naziv visokog učilišta & Vrsta & $\begin{array}{l}\text { Vlasnička } \\
\text { struktura }\end{array}$ & Sjedište & Ispitanik \\
\hline 1. & Veleučilište u Karlovcu & veleučilište & javno & Karlovac & prodekan \\
\hline 2. & Veleučilište u Vukovaru & veleučilište & javno & Vukovar & dekan \\
\hline 3. & Veleučilište Nikola Tesla u Gospiću & veleučilište & javno & Gospić & dekanica \\
\hline 4. & Veleučilište u Šibeniku & veleučilišste & javno & Šibenik & dekan \\
\hline 5. & Poslovno veleučilište Zagreb & veleučilište & $\begin{array}{l}\text { privatno } \\
\text { (gradsko) }\end{array}$ & Zagreb & prodekan \\
\hline 6. & Veleučilište Vern & veleučilište & privatno & Zagreb & prodekanica \\
\hline 7. & Visoko učilište Algebra & veleučilište & privatno & Zagreb & dekan \\
\hline 8. & Visoka poslovna škola PAR & visoka škola & privatno & Rijeka & dekanica \\
\hline 9. & RRIF Visoka škola za financijski menadžment & visoka škola & privatno & Zagreb & dekanica \\
\hline 10. & Edward Bernays Visoka škola & visoka škola & privatno & Zagreb & dekan \\
\hline
\end{tabular}

Intervjui su vođeni posredstvom digitalne platforme Teams, uz prethodno slanje emailom 12 pitanja koja su ispitanicima poslužila za kvalitetniju pripremu odgovora. Što se tiče vremenskog perioda, razgovori su vođeni tijekom veljače i ožujka 2021. godine, što se vremenski poklapa s provedbom online $\mathrm{i} / \mathrm{ili}$ hibridne nastave tijekom cijele

1 Redni broj visokih učilišta u tablici ne prati redni broj ispitanika u intervju kako bi se zaštitio identitet svakog ispitanika. 
2020. godine, odnosno za vrijeme ljetnog semestra akademske godine 2019./2020. i zimskog semestra akademske godine 2020./2021.

Razgovori su snimljeni i sastavljena je bilješka odmah nakon razgovora (usp. Burns, 2000.). U pravilu, razgovori su trajali između 35 i 70 minuta. Protokol obrade ispitanika bio je kronološkim redoslijedom, a radi čuvanja identiteta ispitanika označavani su rednim brojem intervjua, koji je naveden kodnom oznakom „I-1“. Kada se preklapaju razmišljanja i procjene ispitanika, za jednostavniji prikaz korišten je broj ispitanika prema ukupnom uzorku (npr. „8 od 10 ispitanika“ označeno je kao „8/10“.

\section{Rezultati istraživanja}

\section{IP1: U kojoj su mjeri korištene digitalne platforme u internoj komunikaciji i je li se izvodio neki oblik online ili hibridne nastave na pojedinim kolegijima odnosno na razini studijskog programa prije proglašene pandemije?}

Istraživačko pitanje IP1 obuhvaća dva pitanja koja se odnose na primjenu digitalnih platformi u internoj komunikaciji kao i na nastavni proces prije proglašenja pandemije u Republici Hrvatskoj 11. ožujka 2020. godine i objave zatvaranja nekoliko dana kasnije. Većina ispitanika nije uopće ili je vrlo rijetko koristila digitalne platforme za sastanke (uživo) s nastavnicima, stručnim povjerenstvima ili katedrama, konzultacije sa studentima te za druge vrste sastanaka djelatnika i dekanata (8/10). Neki od tih ispitanika naveli su da su iznimno i vrlo rijetko koristili digitalnu platformu, i to Skype ili Skype for Business, za sastanke (3/8), „,na studiju MBA s američkim nastavnicima“ (I-5) ili sjednice: „članovi koji su živjeli u udaljenom mjestu bili su spojeni putem Skypea na sjednice katedri“" (I-8). Dominantni su formalni i neformalni sastanci u fizičkom obliku. Ponekad su se sjednice Stručnog vijeća odvile kao dopisne sjednice (izjašnjavanje putem e-pošte bez komentiranja ili rasprave) (3/10). U internoj komunikaciji korišteni su pomoćni digitalni alati poput platforme za e-učenje za pohranu dokumenata i za "komunikaciju uprava - nastava“ (I-3). Dva ispitanika odgovorila su da su i prije pandemije koristili vlastitu platformu: „Glavna platforma je BigBlueButton - koristi se za sve službene sastanke djelatnika na veleučilištu i za nastavu i konzultacije sa studentima" (I-2). Svi ispitanici odgovorili su da je visoko učilište u komunikaciji s nastavnicima i studentima koristilo standardne digitalne kanale: telefon, e-pošta, poruke unutar intranetskih platformi.

Na pitanje je li se izvodila online ili hibridna nastava prije pandemije odgovor je bio gotovo jednoglasan: visoko učilište „uopće nije izvodilo online odnosno hibridnu nastavu" (7/10). Nastavni proces prije pandemije izvodio se u obliku klasične nastave. Zamijećeno obrazloženje jest što „studijski programi nisu akreditirani za izvođenje nastave na daljinu" (I-2; I-8; I-9). Manjina je također potvrdila da je nastava na daljinu izvođena vrlo rijetko i na malo kolegija (3/10). U tim slučajevima radilo se o spe- 
cifičnim situacijama, ,jedan dio nastave na studiju Poslovne informatike se održavao 'na daljinu' (ukupno deset školskih sati) te cjelokupna nastava Top UP programa u suradnji s Academy of Tourism iz Antalije“ (I-7), ,ponekad, i to uglavnom na stručnom Upravnom studiju zbog nemogućnosti pojedinih nastavnika da nastavu obave 'uživo' za vrijeme zime..." (I-1), „na vrlo malo kolegija..." (I-5), a isti ispitanik ističe da su „sva predavanja prenošena u realnom vremenu bez snimanja dok traje klasična nastava" (I-5).

\section{IP2: Kako je komunikacija promjena na visokom učilištu provedena u od- nosu na prelazak na online i rad od kuće za zaposlene nastavnike i vanjske suradnike u nastavi?}

Istraživačko pitanje IP2 odnosilo za na period samog početka pandemije i prelaska s klasične nastave na nastavu na daljinu tijekom druge polovice ožujka i travnja 2020. godine. Ispitanici su različito opisali kako su organizirali komunikaciju s nastavnicima za vrijeme prvog zatvaranja i prelaska na rad od kuće. Komunikacija s nastavnicima organizirana je na samom početku putem e-pošte (7/10) i izravnom komunikacijom putem telefona (8/10). Manji broj imao je već digitalne platforme za sastanke na daljinu, npr. BigBlueButton (I-2), „Interna komunikacija bila je i prije putem programa Skype Business" (I-5) ili su ih odabrali i stavili u funkciju za zaposlenike prije ili uoči zatvaranja i upućivanja na rad od kuće (4/10). Odgovori ispitanika na to pitanje ukazuju na različitu pripremljenost dekanata za takvu nezapamćenu kriznu situaciju zabrane klasične nastave i upućivanja na rad od kuće. Ipak, odgovori dijela ispitanika ukazuju na to da su dekanati pomno pratili razvoj događaja: „Prateći stanje u inozemstvu i u Hrvatskoj imali smo redovite sastanke na višim razinama i pripremali potencijalna rješenja. Tako smo, neposredno prije lockdowna imenovali uži 'krizni tim' i podijelili uloge“ (I-7). „U internoj komunikaciji s nastavnicima prešli smo odmah na Teams. Prilikom objave lockdowna i zabrane izvođenja klasične nastave, obavijestili smo u roku od dva sata sve studente i nastavnike i potom prešli na Teams“ (I-8). „Prije odlaska na rad od kuće za sve nastavnike (zaposlenici i vanjski suradnici) organiziran je Google Meet tutorijal o načinu upotrebe online platformi“ (I-1), „Bez ikakvih problema. Nismo izgubili niti jedan sat nastave. Putem Skypea“ (I-10).

Dio visokih učilišta bio je zatečen novonastalom situacijom: „Momentalno smo odgodili svu nastavu na tjedan dana, obavijestili o tome sve nastavnike i studente, kako bismo imali dovoljno vremena za pripremu svih potrebnih radnji u vidu prelaska na online nastavu“ (I-6), „Na samom početku tranzicije na online nastavu (16. ožujka) koja nas je sve dočekala nespremne" (I-4). Neka visoka učilišta nisu odmah prešla na komunikacijske platforme u internoj komunikaciji, nego su koristili standardne kanale: „Za vrijeme prvog lockdowna komunikacija se odvijala uglavnom preko maila, a dijelom i telefonski (svi zaposlenici imaju službene mobitele)"(I-3), a neki i društvene mreže poput WhatsAppa i Vibera: „Tijekom prvog lockdowna komunikacija s nastavnicima odvijala se uglavnom putem e-maila, telefonom te unutar WhatsApp odnosno 
Viber grupa. Važne obavijesti vezane uz odvijanje nastavnog procesa bile su također objavljene na web stranici Veleučilišta" (I-4).

Na pitanje u kojoj su mjeri zaposleni nastavnici sudjelovali u odabiru i uspostavljanju digitalne platforme prilikom prelaska na nastavu na daljinu, uglavnom je odgovor ispitanika da je takvu odluku donijela uprava visokog učilišta (dekanat, Stručno ili Upravno vijeće) ili IT-odjel (6/10). Na jednom visokom učilištu uslijedila je rasprava nastavnika prije odabira jedne platforme: „Zaposleni nastavnici na zajedničkom sastanku raspravljali su o odabiru i uspostavljanju komunikacijske platforme prilikom prelaska na online nastavu, a odluka je kasnije potvrđena na Stručnom vijeću koje se održalo putem Zoom platforme" (I-9). Interesantan pokazatelj jest da su tri javna veleučilišta davala preporuku svojim nastavnicima koje platforme mogu koristiti, tako da je u uporabi tijekom ljetnog semestra 2019./2020. godine na istom visokom učilištu bilo korišteno više platformi, a odluku o tome donio je dotični nositelj kolegija.

Na pitanje na koje su poteškoće i moguće otpore zaposlenika nailazili u procesu prelaska na digitalizirani nastavni proces tijekom ožujka i travnja 2020. godine, dio ispitanika ističe da su naišli na djelomičan otpor zaposlenika (4/10), dok dio ističe da ga uopće nije bilo (4/10). Tako npr. „Dio (30-ak \%) nastavnika nije bio spreman prihvatiti MS Teams i Zoom te su koristili e-learning sustav (postavljali su isključivo ppt prezentacije ili druge nastavne materijale u Wordu, tj. nisu držali klasična predavanja online u realnom vremenu)“ (I-3). Bilo je i otpora prema snimanju nastave: „Dio nastavnika je imao velik otpor od predavanja na daljinu zbog mogućeg snimanja predavanja.“ (I-2). Probleme kod prelaska na nastavu na daljinu imali su djelomično „stariji nastavnici koji nisu imali adekvatnu internet vezu kod kuće" (4/10). Dekanati su imali razumijevanja za početne otpore nekih nastavnika, zbog „straha od promjena tj. novih tehnologija" (I-1, I-6, I-7). Također je bilo problema oko informatičke opreme, pa su neka visoka učilišta nabavila svojim nastavnicima grafičke tablete, mikrofone, kamere, slušalice itd. (I-5, I-7). Organizirani su mrežni seminari (engl. webinar), izrada tutorijala za nastavu na daljinu, dokumenti s pitanjima i odgovorima, potpora ITslužbe. Platforme koje su bile korištene prilikom prelaska na digitalnu nastavu na visokim učilištima bile su Zoom (5/10), Teams (4/10), Skype for Business ili Skype (3/10), Adobe Connect (2/10), Google Meet (1/10), vlastiti proizvod BigBlueButton (1/10) kao i Merlin (2/10) i Loomen (1/10).

\section{IP3: Kakva su bila prva iskustva studenata i nastavnika uoči završetka nastav- nog procesa u ljetnom semestru i evaluacije kao priprema za novu akademsku godinu 2021./2022.?}

Istraživačko pitanje IP3 obuhvaća klaster od četiri pitanja koja su vremenski vezana za završetak prvog potpunog zatvaranja, kada je stupila na snagu relaksacija, a uoči početka ljeta 2020. godine. Većina visokih učilišta uvela je promjene u internoj komunikaciji s nastavnicima, studentima i u nastavnom procesu nakon iskustva ljetnog 
semestra, a za potrebe pripreme nove akademske godine 2020./2021. jer se nadalo da će nastava iz digitalnog oblika prijeći na hibridnu nastavu. Gotovo svi ispitanici odgovorili su da su za nastavnike organizirali razne edukacije i mrežne seminare radi poboljšanja nastave na daljinu i interne komunikacije (8/10). Mrežni seminari bili su usmjereni na učinkovito korištenje digitalnih platformi, ne samo za nastavu uživo nego i za korištenje sustava Merlin (3/10). Informatičke službe kreirale su nove upute (pisane i u videozapisu) za poboljšanje rada na platformama (3/10).

Na pitanje kakve promjene su uveli u internoj komunikaciji s nastavnicima, studentima i u samom nastavnom procesu nakon iskustva ljetnog semestra, a povodom početka nove akademske godine 2020./2021. ispitanici ističu razne promjene. Naime, polovica ispitanika ističe da su promijenili prethodno preferirane platforme u digitalnoj nastavi (5/10). Tako su napustili prvo odabrane platforme (Skype, Adobe Connect) i za novu akademsku godinu 2020./2021. prebacili se na Teams (I-5, I-10) odnosno potpuno novu aplikaciju Discord (I-9). Jedan ispitanik ističe da su nasuprot prvobitnoj odluci o samostalnom izboru platforme od nastavnika za novu akademsku godinu donijeli formalnu odluku da su „sustav za e-učenje Merlin i Microsoft Teams [...] obvezne platforme za e-učenje i za provedbu nastavnih aktivnosti“ (I-4). Slično je reagirao i drugi ispitanik: „kupljeno je 20 licenci za korištenje Zoom aplikacije (neki nastavnici preferiraju i dalje MS Teams) “(I-3). Neki ispitanici dopunjuju svoje digitalne aplikacije: „svi kolegiji imaju svoju digitalnu inačicu u Merlin sustavu Srca“ (I-2). U mrežnom nastavnom procesu „povećali smo broj gostujućih predavanja jer su svi otvoreniji za suradnju ako ista ne iziskuje pretjeran napor za putovanje“ (I-1).

Dio ispitanika komentira da je u internoj komunikaciji veći odaziv na mrežne sastanke i dostupniji su (4/10) te da su omogućene konzultacije i obrane završnih i diplomskih radova na daljinu (4/10). Redoviti su semestralni sastanci zaposlenika, koji se održavaju hibridno (I-7): „komunikacija sa studentima i nastavnicima kao i do sada odvija se kontaktno (uz prethodnu najavu i uz sve epidemiološke mjere) te online u radnom vremenu tajništva, referade i knjižnice" (I-10). Slično je i u komunikaciji sa studentima: „Stvoren je tim unutar Microsoft Teamsa za 18 predstavnika godina koji čine Studentski zbor u kojemu su pročelnici Odjela i prodekan za nastavu" (I-8). Konzultacije i sastanci sa studentima odvijaju se uglavnom u digitalnom obliku (7/10).

Na pitanje može li model rada od kuće i stvaranje ureda na daljinu za nastavnike istovjetno zamijeniti klasični način koordinacije zadaća uz fizičku prisutnost na visokom učilištu, odgovori su vrlo jasni: rad od kuće i ured na daljinu ne mogu zamijeniti klasični način rada (9/10). Razlozi idu u pravcu toga da je socijalna interakcija uz fizičku prisutnost neophodna, ali priznaje se da postoje okolnosti kada bi se rad od kuće mogao kombinirati s klasičnim. Odgovori poput „ne može zamijeniti klasični način koordinacije zadaća uz fizičku prisutnost na veleučilištu. Može pomoći u kriznim situacijama“ (I-2) ili ako je privremenog karaktera: „stvaranje ureda na daljinu za 
nastavnike može biti tek nadopuna, tj. privremena zamjena za klasičnu nastavu“ (I-3). Interesantna su iskustva nakon dugotrajnog rada od kuće uz opciju izbora: „Pustili su zaposlenicima da rade od kuće kada hoće, iako 98\% zaposlenika radi u uredu. Sastanci su online, ali svi iz svojih ureda“(I-5). Ističe se da je fizički rad učinkovitiji: „[...] brže i efikasnije rješavati uživo" (I-7). Ocjena je jednog ispitanika o mogućem fleksibilnom pristupu uz dominantan rad u uredu: „Moguće su prilagodbe i hibridna rješenja. U dobrom dijelu rad od kuće može pomoći u fleksibilnosti radnog vremena, pritom postoji određeni izazovi poput uvjeta rada kod kuće, dobar dio nastavnika nema uvjete za home office" (I-8). Isti ispitanik ističe iskustvo da „kod nekih nastavnika dolazi do preopterećenosti, kod drugih do manjeg učinka rada doma nego u uredu“. Jedan ispitanik skreće pozornost na aspekt ljudske potrebe za socijalnom interakcijom: „Socijalna interakcija je neophodna, a to dokazuje i stalna potreba za konzultacijama studenta i nastavnika, nastavnika (ponajprije vanjskih suradnika) s administracijom" (I-9).

Na pitanje jesu li proveli ankete o zadovoljstvu nastavom na daljinu sa studentima i nastavnicima i kakve su zaključke izveli iz toga, većina ispitanika odgovara da su proveli (barem jednu) anketu o zadovoljstvu studenata (8/10). Dio njih ističe da su već radili dvije studentske ankete, u ožujku 2020., po završetku ljetnog semestra 2019./2020. i/ili tijekom ili na završetku nastave u zimskom semestru 2020./2021. godine (3/8). Oni koji nisu proveli anketu, planiraju je provesti u proljeće 2021. godine (2/2). Manji dio ispitanika odgovorio je da su proveli barem jednu anketu i s nastavnicima $(4 / 10)$.

Među ispitanicima postoje podijeljena mišljenja o nastavi na daljinu (manja kvaliteta za oblik stručnog studija naspram novih modela online ili hibridne nastave kao nadogradnje). Komentari poput „Online nastava nikada ne može zamijeniti klasični način poučavanja 'kontaktnim putem"“ (I-10), „studenti vide online nastavu kao nužno zlo“ (I-5) odnosno „mogu nadopuniti, ne zamijeniti“ (I-1) idu u pravcu koncepta hibridnog modela nastave, koji je prihvatljiviji, uz naglasak na klasičnu nastavu, iako nastavu na daljinu „studenti ne vide kao dugoročno rješenje“ (I-8). Također, na nekim visokim učilištima rezultati studentske ankete o nastavi na daljinu podijeljeni su: „Oko 50\% studenata (uglavnom izvanrednih) čeka povratak u predavaonice, dok dio želi nastaviti s online nastavom"(I-9). No, studenti su zbog izvanrednih okolnosti bili zadovoljni nastavom na daljinu (6/10), u manjoj mjeri nisu (3/10).

\section{IP4: Jesu li se adaptirali ciljevi, strategije i alati u internoj komunikaciji?}

Istraživačko pitanje IP4 obuhvaća dva pitanja. U kontekstu interne komunikacije, prvo pitanje usmjereno je na to jesu li se promijenili ili su postavljeni novi ciljevi i strategije interne komunikacije na visokom učilištu. Skoro svi ispitanici ističu da nisu mijenjali ciljeve i strategije interne komunikacije u formalnom smislu, donošenjem dokumenta i odluka kroz stručna vijeća ili druga formalna tijela $(9 / 10)$. No, dio is- 
pitanika odgovorio je da „nastoje posložiti najbolji model“ (3/10). Po tom pitanju za ispitanike je značajnije iskustvo što gotovo svi implementiraju digitalne platforme u internoj komunikaciji s nastavnicima, djelatnicima u referadi i administraciji te studentima za razne oblike razgovora, konzultacija, neformalnih sastanaka i formalnih sjednica $(9 / 10)$.

Stoga se drugo pitanje nadovezuje na prethodno kroz opisivanje najčešćih komunikacijskih alata i kanala koji se koriste u internoj komunikaciji. Tradicionalni tehnološki alati poput e-pošte i telefona ostaju kod svih ispitanika prisutni kao i postojeće mrežne stranice i intranet platforme za e-učenje ili platforme za ispitni proces koje su visoka učilišta koristila i prije pandemije bolesti COVID-19 (Studomatic/Eduneta, Loomen, Merlin, Infoeduka/Beduka itd.). Globalna pandemija donijela je snažnu digitalnu transformaciju ne samo u nastavnom procesu nego i u internoj komunikaciji visokog učilišta. Ispitanici ističu da će nove digitalne platforme i aplikacije ostati u primjeni i nakon pandemije za virtualne susrete uživo $(9 / 10)$. Na ovom ograničenom uzorku $(\mathrm{N}=10)$ primijećena je, u internoj komunikaciji, pojačana uporaba Microsoft Teamsa (5/10) u odnosu na Zoom (2/10), s time da na dvije ustanove uz Teams za razgovore koriste istodobno Skype for Business ili Skype (I-4, I-5), a na jednoj koja koristi Zoom u primjeni je i platforma Discord (I-9). Osim Teamsa i Zooma koristi se Google Meet(I-1) te vlastiti digitalni proizvod BigBlueButton (I-2).

$\mathrm{Uz}$ „tradicionalne“ tehnološke alate, sustave za e-učenje i nove digitalne platforme, $\mathrm{u}$ dodatnoj su uporabi za internu komunikaciju Facebook stranica za studente (I-3), MS Planner za administrativno-poslovnu komunikaciju (I-6), Forms za ankete i WhatsApp (I-8).

\section{IP5: Koje se preporuke mogu dati u smislu digitalne transformacije nastav- nog procesa?}

Istraživačko pitanje IP5 vezano je uz davanje preporuka ispitanika za daljnju digitalnu transformaciju nastavnog procesa. Pandemija bolesti COVID-19 utjecala je na snažnu digitalnu transformacije nastavnog procesa jer je prije pandemije korišten tek ograničen dio potencijala koji nudi sustav e-učenja te pogotovo digitalne platforme za nastavu uživo, koje skoro nisu bile u uporabi. Nitko od ispitanika u uzorku nije spomenuo da ima akreditirani online studij. Većina ispitanika smatra da je nastava na daljinu u ovim izvanrednim okolnostima bila dobra ili čak ,iznimno dobra i učinkovita“ (7/10). Ima i izdvojenih stavova po pitanju pada znanja kod studenata, u jednom slučaju navodi se „oko $15 \%$ veliki indikator uspješnosti digitalnih platformi“, i to za specifične oblike praktične nastave na stručnom studiju poput laboratorijskih vježbi (I-5), dok u drugom slučaju usporedba ocjena i studentskih anketa $s$ prošlim godinama pokazuje „trend visokih ocjena nastave i nastavnika" (I-7). 
Među ispitanicima postoje podijeljena mišljenja o razvoju digitalne nastave u razdoblju nakon pandemije. Klasična nastava smatra se kvalitetnijim oblikom nastave (8/10). Neki izdvojeni stavovi ispitanika naglašavaju da se kroz kontaktnu nastavu „mogu razvijati osobna i društvena odgovornost te različite kompetencije sudjelovanjem studenata u raspravama, timskom radu i zajedničkim projektima“" (I-7).

Nastava na daljinu moguće je rješenje za studente u radnom odnosu (izvanredni studenti) (6/10) i kao „ponuda online studija za svjetsko tržište“ (I-5). Ispitanici smatraju da je nemoguće zamijeniti laboratorijske vježbe, praktikume, terensku nastavu i stručnu praksu mrežnim formatom $(7 / 10)$. No, moguća su rješenja hibridna nastava tj. online nastava kao nadogradnja klasičnoj nastavi (I-6, I-8). Ispitanici smatraju da ćemo se vratiti na pretežitu klasičnu nastavu, uz kombinaciju s hibridnom nastavom na nekim kolegijima (6/10), no koristit će se puno više alati koje nude digitalne platforme. Jedan ispitanik ima izdvojeno mišljenje o istovremenoj klasičnoj i online nastavi: neće se ići u „dodatnu digitalizaciju, ali dozvoljava paralelni prijenos klasične nastave u digitalnom obliku uživo, za sada se ne snima, možda će uvesti snimanje“ (I-5).

Dio ispitanika smatra da će „učenje novih alata zasigurno olakšati nastavni proces“ (I4), odnosno da „nastavnici nisu educirani za kreiranje digitalnih sadržaja“ (I-2). Iz tih odgovora može se zaključiti da je izazov investirati u digitalne kompetencije.

Ispitanici daju svojevrsnu preporuku da visoka učilišta, studenti i nastavnici te cijela akademska zajednica moraju investirati u infrastrukturu, između ostalog i brži internet. Stavovi poput „pojedini studenti se žale na slabu propusnost podataka“ (I-2, I-3, I-6, I-9) i da je moguće rješenje ,jakost internetske veze, posebno uvođenje 5G mreže" (I-6). Iz odgovora ispitanika koji daju dekani/prodekani u županijskim središtima izvan Zagreba i Rijeke primijećeno je da je internetska veza sporija (4/10).

\section{Zaključak}

Nastupanje pandemije bolesti COVID-19, koja je u Hrvatskoj polovicom ožujka 2020. godine dovela do zaključavanja javnog života, promijenilo je u potpunosti način rada visokih učilišta. U svega nekoliko dana prilagodbe cijeli nastavni proces u visokom obrazovanju prelazi na daljinu. To nije bio izazov samo za sveučilišne studije nego i za izvođenje nastave u duhu koncepta stručnih studija, na kojima studira skoro svaki treći student u Hrvatskoj. Naime, uz predavanja, kao nastavne oblike studenti na stručnim studijima imaju naglašenu praktičnu nastavu, praktikume, laboratorijske vježbe i terensku nastavu. Rad od kuće postaje obvezatan, a time se privremeno promijenila i paradigma interne komunikacije. $U$ trokutu između studenata, nastavnika i administracije/dekanata pronalazi se nov način koordinacije radnih procesa, čiji glavni alat postaju digitalne mreže. Interna komunikacija postaje od strateškog značaja za daljnje funkcioniranje nastavnog procesa, potpornih i upravljačkih procesa, uz zamje- 
nu klasičnih alata koji su vezani uz fizičku prisutnost na visokom učilištu i koji više ne mogu biti od koristi.

Upravo je to bio cilj ovog istraživanja, u kojem je sudjelovalo deset čelnika veleučilišta i visokih škola. Polustrukturirani dubinski intervju koji je korišten u istraživanju daje odgovore na 12 pitanja, iz čega se može dobiti reprezentativan uvid u komunikaciju promjena i interne komunikacije veleučilišta i visokih škola tijekom 2020. godine, odnosno za razdoblje od dva semestra u izvanrednim okolnostima koronavirusa. Iako se rezultati dobiveni ovim istraživanjem ne smiju generalizirati na cijelo visoko obrazovanje, oni daju dobar uvid u digitalnu transformaciju interne komunikacije uključujući i nastavni proces stručnih studija, koji čine drugi stup binarnog sustava u visokom obrazovanju.

U analizi su promatrana dva aspekta, jedan je nastavni proces, a drugi je interna komunikacija. Klasična nastava smatra se kvalitetnijim oblikom nastave. Mišljenja studenata i nastavnika slična su u kontekstu ocjene je li klasična ili online nastava bolje rješenje. Nastava na daljinu moguće je rješenje za studente u radnom odnosu ili kao nadogradnja unutar koncepta hibridne nastave. Pretpostavka je edukacija nastavnika u smislu korištenja dodatnih alata koje nude digitalne platforme i snažna investicija u digitalnu infrastrukturu, koja uključuje brži i dostupniji internet. Moguće rješenje nova je 5G tehnologija. Provedene su ankete zadovoljstva nastavom na daljinu sa studentima i djelomično s nastavnicima.

Rezultati istraživanja o internoj komunikaciji pokazali su pojačanu uporabu Microsoft Teamsa nasuprot Zooma. Zoom je učinkovita platforma na kojoj se preglednije mogu održati veće videokonferencije, dok Microsoft u Teams integrira razne alate iz svojeg sustava, što olakšava interakciju među zaposlenicima. Istraživanje pokazuje da visoka učilišta nisu promijenila ili postavila nove ciljeve i strategije interne komunikacije, ali zato koriste nove digitalne alate. Također, veći je odaziv na digitalne sastanke u internoj komunikaciji. Razvijaju se koncepti virtualnih sastanaka kao dodatni oblici interne komunikacije, što će u budućnosti olakšati internu, ali i eksternu poslovnu komunikaciju.

U budućnosti je svakako potrebno provesti istraživanje na hrvatskim sveučilištima, što je i glavna preporuka za buduća istraživanja koja će preispitivati internu komunikaciju u razdoblju nakon pandemije koronavirusa. Daljnja istraživanja za oba binarna sustava visokog obrazovanja mogu pridonijeti preciznijoj procjeni primjene hibridne nastave uz optimalni omjer klasične i online nastave.

Klasična nastava treba ostati prioritetni model za sve oblike praktične i terenske nastave. Kod teorijskih sadržaja u obliku predavanja moguća je kombinacija s nastavom na daljinu uživo, što osigurava dvosmjernu asimetričnu komunikaciju sa studentima s obzirom na interakciju u stvarnom vremenu, dok je snimljena online nastava samo prijenos znanja bez mogućnosti sudjelovanja studenata na nastavi. 
Preporuka autora jest da hibridna ili online nastava mogu pomoći u internacionalizaciji, odnosno privlačenju stranih studenata na upisivanje hrvatskih studijskih programa. Interesantna je mogućnost u tom pogledu privući studente potomke hrvatskog iseljeništva iz Europe i prekomorskih država. Stoga je važno razvijati hibridni model nastave i na engleskom jeziku uz potencijal pridobivanja studenata s latinsko-američkog kontinenta. Digitalna transformacija visokih učilišta nema povratka i otvara mnoge nove izazove!

\section{Literatura}

1. Agencija za znanost i visoko obrazovanje (2020). Mozvag - preglednik studijskih programa. Broj javnih i privatnih učilista. https://mozvag.srce.hr/preglednik/vu/ tip?lang=hr. (Pregledano 12. travnja 2021.)

2. Argenti, P. (2009). Corporate Communication. New York: McGraw-Hill.

3. Armbrecht, W. (1992). Innerbetriebliche Public Relations. Grundlagen eines situativen Gestaltungskonzepts. Opladen: Westdeutscher Verlag Arnott.

4. Bedeković, V. (2011). Osnove metodologije stručnog i znanstvenog rada. Virovitica: Visoka škola za menadžment u turizmu i informatici u Virovitici.

5. Buchholz, U. (2019). Interne Hochschulkommunikation, u: Fähnrich, B.; Julia Metag, J.; Post, S.; Schäfer, M. (Ur.). Forschungsfeld Hochschulkommunikation. Wiesbaden: Springer VS, 141-164.

6. Burns, R. B. (2000). Introduction to Research Methods, 4. izdanje. London: Sage Publications.

7. Einwiller, S.; Klöfer, F. i Nies, U. (2006). Mitarbeiterkommunikation, u: Schmid, B. F. i Lyczek, B. (Ur.). Unternehmenskommunikation. Kommunikationsmanagement aus Sicht der Unternehmensführung. Wiesbaden: Gabler, 221-260.

8. Europska komisija (2021). Pregled obrazovanja i osposobljavanja za 2020-Hrvats$k a$. https://op.europa.eu/webpub/eac/education-and-training-monitor-2020/ countries/croatia_hr.html\#seven. (Pregledano 16. travnja 2021.)

9. Greenberga Zalite, G. and Zvirbule, A. (2020). Digital Readiness and Competitiveness of the EU Higher Education Institutions: The COVID-19 Pandemic Impact. Emerging Science Journal, 4 (4): 297-304.

10. Grunig, L; Grunig, J. and Dozier, D. (2002). Excellent Public Relations and Effective Organisations. A Study of Communication Management in Three Countries. Mahwah, NJ: Lawrence Erlbaum.

11. Jugo, D. (2017). Menadžment kriznog komuniciranja. Zagreb: Školska knjiga/ Edward Bernays Visoka škola za komunikacijski menadžment.

12. Krämer, K., Pfizenmayer, A. (2020). Interne Kommunikation in Zeiten von COVID-19. Wie die Pandemie die interne Kommunikation verändert hat eine qualitative Studie. Working Papers in Applied Linguistics 19. Winterthur: ZHAW Zürcher Hochschule für Angewandte Wissenschaften. 
13. Lies, J. (2015). Praxis des PR Managements. Wiesbaden: Springer Fachmedien.

14. Mast, C. (2006). Change Communication, u: Schmid, B. F. i Lyczek, B. (Ur.). Unternehmenskommunikation. Kommunikationsmanagement aus Sicht der Unternehmensführung. Wiesbaden: Gabler, 403-434.

15. Milas, Z. (2011). Uvod u korporativnu komunikaciju - teorijski aspekti i organizacijski modeli. Zagreb: Noveli Millenium

16. Ministarstvo zdravstva (2020). Odluka o proglašenju epidemiju bolesti COVID-19 uzrokovana virusom SARS-CoV-2. https://tinyurl.com/4239c56z. (Pregledano 15. travnja 2021.)

17. Ministarstvo znanosti i obrazovanja (2020). Upitnik o izvodenju nastave na daljinu na visokim učilištima u periodu od 26. 3. 2020. do 1. 4. 2020. https:// tinyurl.com/3tzs3sf4. (Pregledano 17. travnja 2021.)

18. Odluka o obustavi izvođenja nastave u visokim učilištima, srednjim i osnovnim školama te redovnog rada ustanova predškolskog odgoja i obrazovanja i uspostavi nastave na daljinu, Narodne novine 29 od 2020.

19. Röttger, U. (2000). Public Relations - Organisation und Profession: Öffentlichkeitsarbeit als Organisationsfunktion. Eine Berufffeldstudie. Wiesbaden: VS Verlag für Sozialwissenschaften.

20. Tkalac Verčić, A.; Sinčić Ćorić, D. i Pološki Vokić, N. (2010). Priručnik za metodologiju istraživačkog rada. Zagreb: M.E.P. d.o.o.

21. Tkalac Verčić, A. (2015). Odnosi s javnošću. Zagreb: Hrvatska udruga za odnose $s$ javnošću.

22. Tomić, Z. (2016). Odnosi s javnošću - teorija i praksa. Zagreb-Sarajevo: Synopsis.

23. Vijeće veleučilišta i visokih škola (2021). Stručni studiji. https://vvivs.hr/strucnistudijil. (Pregledno 11. travnja 2021.)

24. Zakon o znanstvenoj djelatnosti i visokom obrazovanju, Narodne novine 123 od 2003.

25. Zulić, A. (2020). U potresu stradalo čak 20 fakulteta: Ovako danas izgledaju Ekonomija, Medicina, Pravo, FFZG, PMF. MojFaks.com - portal za studente, 23. ožujka 2020. https://mojfaks.dnevnik.hr/akademska-cetvrt/jos-jedan-zagrebacki-fakultet-pretrpio-ogromnu-stetu. (Pregledano 18. travnja 2021.) 


\title{
Rethinking Internal Communication in Higher Education Environment COVID-19: Guidelines for the Future
}

\author{
Zdeslav Milas
}

Edward Bernays University College, Zagreb, Croatia

e-mail: zdeslav.milas@bernays.hr

\section{Dorotea Milas}

Zagreb School of Business, Croatia

e-mail:dorotea.milas@pvzg.hr

\begin{abstract}
The year 2020 remains remembered for the global coronavirus pandemic (COVID-19) and it has radically changed our way of life. The internal communication of higher education institutions becomes crucial under circumstances of interruption of traditional teaching in classrooms, the closing of buildings for students, the transition to work from home and the establishment of digital platforms. The rapid adaptation to organizational communication change patterns leads to the answer that internal communication has become of strategic importance for the further functioning of universities, faculties, universities of applied sciences and colleges.
\end{abstract}

The aim of this paper is to analyze the paradigm shift of internal communication in the coronavirus environment in higher education professional study programs. The purpose is to become acquainted with the challenges in internal communication during the digital transformation of the teaching process and to compare whether the goals and instruments in the internal communication of the higher education institution have changed. As research method, a semi-structured in-depth interview with deans or vice deans for academic affairs was selected on a sample of ten selected universities of applied sciences or colleges that offer accredited professional study programs in Croatia. The semi-structured interview method was deliberately selected to generate potentially new ideas and questions arising from the answers based on the experiences of the respondents who were responsible for adapting the distance teaching process and communicating with teachers and students. The radical change in the teaching methods has strongly impacted digitalization in higher education, and from the analysis of respondents' answers, the authors provide guidelines for the future of internal communication as a strategic function in the management of higher education institutions. The post-pandemic period is creating a new normal in the functioning of internal communication processes, which are closely related to the digital transformation of higher education institutions.

Key words: internal communication, digital transformation, online teaching, change communication, higher education institution. 